\title{
Feed Parameters Influencing the Breeding of Mealworms (Tenebrio molitor)
}

\author{
Jiř́i Mlček ${ }^{1}$, Martin Adámek ${ }^{2,3}$, Anna Adámková ${ }^{1, *} \mathbb{E}$, Jiř́i Matyáš ${ }^{4} \mathbb{D}$, Martina Bučková ${ }^{1} \mathbb{D}$, Martina Mrázková ${ }^{1}$, \\ Robert Vícha ${ }^{5}{ }^{\infty}$, Radek Vychodil ${ }^{1}$, Ivana Knížková ${ }^{6}{ }^{-1}$ and Zdeněk Volek ${ }^{7}$
}

1 Department of Food Analysis and Chemistry, Faculty of Technology, Tomas Bata University in Zlin, Vavreckova 275, 76001 Zlin, Czech Republic; mlcek@utb.cz (J.M.); buckova@utb.cz (M.B.); mmrazkova@utb.cz (M.M.); r_vychodil@utb.cz (R.V.)

2 Department of Physics and Materials Engineering, Faculty of Technology, Tomas Bata University in Zlin, Vavreckova 275, 76001 Zlin, Czech Republic; m2adamek@utb.cz

3 Department of Microelectronics, Faculty of Electrical Engineering and Communication, Brno University of Technology, Technicka 3058/10, 61600 Brno, Czech Republic

4 Centre of Polymer Systems, University Institute, Tomas Bata University in Zlin, Trida T. Bati 5678, 76001 Zlin, Czech Republic; matyas@utb.cz

5 Department of Chemistry, Faculty of Technology, Tomas Bata University in Zlin, Vavreckova 275, 76001 Zlin, Czech Republic; rvicha@utb.cz

6 Department of Livestock Technology and Management, Institute of Animal Science, Pratelstvi 815/107, 10400 Prague, Czech Republic; knizkova.ivana@vuzv.cz

Citation: Mlček, J.; Adámek, M.; Adámková, A.; Matyáš, J.; Bučková, M.; Mrázková, M.; Vícha, R.; Vychodil, R.; Knížková, I.; Volek, Z. Feed Parameters Influencing the Breeding of Mealworms (Tenebrio molitor). Sustainability 2021, 13, 12992. https://doi.org/10.3390/su132312992

Academic Editors: Ewelina Zielińska, Urszula Pankiewicz, Monika Sujka and Ada Margarida Correia Nunes Da Rocha

Received: 18 October 2021

Accepted: 22 November 2021

Published: 24 November 2021

Publisher's Note: MDPI stays neutral with regard to jurisdictional claims in published maps and institutional affiliations.

Copyright: (c) 2021 by the authors. Licensee MDPI, Basel, Switzerland. This article is an open access article distributed under the terms and conditions of the Creative Commons Attribution (CC BY) license (https:/ / creativecommons.org/licenses/by/ $4.0 /)$.
7 Department of Nutritional Physiology and Animal Product Quality, Institute of Animal Science, Pratelstvi 815/107, 10400 Prague, Czech Republic; volek.zdenek@vuzv.cz

* Correspondence: aadamkova@utb.cz

Abstract: With the growing public interest in edible insects, breeders are forced to increase the volume of production and shorten the life cycle of farmed insects. The exact composition of the feed is the know-how of each manufacturer. The aim of this work was to determine the general impact of individual conventional types of feed (bran, whey, raw ware potatoes) on the life cycle rate of Tenebrio molitor (TM), larval mortality and the content of fats, fatty acids and nitrogenous substances in larvae and their excrements. For the reasons of sustainability of the state of nature and waste disposal, polystyrene foam was added to the experiment as feed. The experiment was performed in two phases-rearing for 21 weeks and 5 weeks. The nitrogen content was determined using the Kjeldahl method (ISO 1871: 2009), the fat content by the Soxhlet method and the fatty acid profile using a gas chromatograph with a flame ionization detector (FID). The results of the work show that the basis of the TM feed is wheat bran, not only due to the observed low larval mortality (45\% over 21 weeks) and their optimal nutritional value (nitrogenous substances 53.6\% DM, fat $37.1 \% \mathrm{DM}$, the highest total fatty acid content) but also due to the higher speed of TM development. Lower larval mortality during rearing was found when feeding dried whey and raw ware potatoes, but the development cycle rate was low. This confirmed that the bran as a feed allowed a fast life cycle with good larval nutritional parameters. From a nutritional and reproductive point of view, TM appeared to be a suitable alternative to animal production. Polystyrene as a feed, tested for biodegradation by TM larvae, caused the highest larval mortality (75\% in 21 weeks). However, the content of nitrogenous substances in the larvae increased to $69.77 \%$, in the excrement, it even increased to $82.68 \%$, and there was no cannibalism among the larvae. The work thus demonstrated the possibility of biodegradation of polystyrene using TM larvae with an increase in nitrogenous substances in both larvae and excrement.

Keywords: Tenebrio molitor; feed; polystyrene

\section{Introduction}

Edible insects are one of the oldest animal foods in the human diet. Although more than 2 billion people consume edible insects [1], there has been a rather negative attitude 
towards insect consumption in developed countries in Europe and America. At present, however, this attitude is gradually changing. According to the Food and Agriculture Organization (FAO), insects are particularly important as food due to rising animal protein cost, food insecurity, environmental pressures, population growth and growing protein demand. The FAO suggests that insects could become an alternative source of protein that is comparable to other animal proteins. Insects are a good source of food high in fats, proteins, fiber and some vitamins and minerals. The environmental benefits of insect farming are also significant, based on the high efficiency of insect conversion for feed, lower greenhouse gas emissions, less use of water and arable land and the use of insect-based bioconversion as a tradable solution to reducing food waste [2-4].

Legislation is also helping to change the attitude of European consumers. As of 1 June 2021, Commission Implementing Regulation (EU) 2021/882 was adopted, authorizing the placement on the market of dried larvae of Tenebrio molitor as novel foods [5]. As insect-based proteins are considered one of the key areas of research under Horizon Europe (the EU framework program for research and innovation) [6] and, according to the FAO, insect consumption makes a positive contribution to the environment, human health and livelihoods (Farm to Fork a Green Deal [5]), more insect species can be expected to be authorized.

The darkling beetle (Tenebrio molitor) is a model edible insect and with the domestic cricket (Acheta domesticus) and the banana cricket (Gryllus assimilis) is one of the most commonly bred and propagated species of edible insects. The efficiency of rearing is influenced by a number of factors. The main factors include the developmental stage, temperature, relative humidity, feed and the country of rearing. Other factors include the access of light, air and sex of farmed individuals. These factors can significantly affect rearing - speeding up and securing rearing, improving its yield and promoting its stability $[7,8]$.

The amount of feed and its composition are among the key factors in the whole rearing. The improper choice of feed can slow down the larvae development to such an extent that it is unable to pupae and, in extreme cases, not to undress, which can result in the accumulation of undesirable substances and lead to death $[9,10]$.

When the feed is completely weaned, up to $90 \%$ of the larvae from the total rearing die after 3 months (the larvae live from their body supplies). Therefore, the larvae are not able to survive for more than 4 months without food. When fed only bran, only $18 \%$ of the larvae die after 3 months [10].

A lack of food or a certain nutrient also leads to an increase in the incidence of cannibalism, in which the larvae try to obtain possible nutrients from other larvae or pupae. Improvement can be achieved by increasing the dose or adding some of its components (starch, proteins, vitamins, etc.), which significantly affect the overall development time in the order of weeks. In addition to rearing efficiency, feed also significantly affects the nutritional value of edible insects [11-14]. It is possible to evaluate the quality of insects mainly according to the fat content because during starvation it decreases, and at the same time, the specific taste of the insect changes. On the contrary, sufficient feed with a high protein content has a positive effect on larval growth [11,13].

As a basic component of insect feed, mainly by-products from plant production are commonly used due to their low price. Ingredients from common wheat bran to corn grits are used. To guarantee the quality of feed and increase the efficiency of rearing and production of insects, the feed is further enriched. However, some forms of feed are not suitable, and supplementation should be avoided [11].

Supplementation can be from both plant and animal. From the plant, mainly fruit, vegetables, root crops or oilseeds are used. In the case of animal supplements, milk powder, blood meal or meat-and-bone meal is used. Nutritional supplements for livestock can also be used, especially to improve immunity during the seasons when plant feeds are not enough to meet the needs of insects [15]. 
In addition to conventional feeds, the ability of Tenebrio molitor to biodegrade polystyrene has been identified and demonstrated $[16,17]$ by Exiguobacterium sp. strain YT2, which live in their digestive tract $[17,18]$. This demonstrates the ability to use insects to biodegrade plastic waste and increase the sustainability of current environmental levels.

The exact composition of the feed to achieve the highest possible production of insects in the given rearing conditions is the know-how of each producer and the general recommendations often do not have a significant effect in specific operations. This study therefore focused on specifying the effect of feed on life cycle speed, mortality and the content of fats, fatty acids and nitrogenous substances. Different types of feed were used for this work-bran, whey, potatoes and polystyrene foam.

\section{Materials and Methods}

\subsection{Rearing and Life Cycle Observation}

To evaluate the developmental cycle and nutritional values of the darkling beetle (Tenebrio molitor), samples of larvae (mealworms) were purchased from a breeder (Radek Frýželka, Brno, the Czech Republic) and subsequently bred in two phases at Tomas Bata University in Zlín.

The first phase was focused on determining the effect of feed on mortality and larval life cycle for 21 weeks. In the first phase, 80 pieces of larvae were selected, which were weighed, measured and divided into four groups of 20 pieces so that the same conditions for evaluation were achieved in all groups by their size and weight. Each group was reared in a plastic box measuring $(250 \times 180 \times 70) \mathrm{mm}$. Each group received a certain type of feed (1st group - wheat bran, 2nd group — ware potatoes, 3rd group — dried whey, 4th group-polystyrene foam), which was not changed throughout the first phase of the experiment. The initial amount of feed was $10 \mathrm{~g} /$ box. The feed was supplemented so that the larvae were fed ad libitum. The feed was checked and replenished once or twice a week.

The second phase was focused on the rearing of larvae in large quantities for 5 weeks to determine the behavior of large-scale rearing and to ensure a sufficient amount of material for the determination of individual nutrients. Larvae at approximately the same developmental stage were weighed and divided into 4 groups (one group-one type of feed). The initial weight of each group was $500 \mathrm{~g}$. Each group was placed in a plastic box measuring $(600 \times 400 \times 200) \mathrm{mm}$. Feed of $400 \mathrm{~g} /$ box for wheat bran, ware potatoes and dried whey and $50 \mathrm{~g} / \mathrm{box}$ for polystyrene foam was then added to each box and was not changed throughout the second phase of the experiment. The amount of feed was adjusted according to the experience from the first phase of the experiment. The feed, despite the different weights, was supplied sufficiently (ad libitum) and was checked and replenished once or twice a week.

The insects were inspected, fed and weighed at regular intervals. When feeding or weighing, the exuviae, which have a very low weight, were first separated. Therefore, the exuviae were removed with a weak vacuum cleaner or blown away by a fan. Subsequently, feed and excrement from larvae, pupae and dead individuals were separated using sieves. Larvae, pupae and dead individuals were collected by hand. The pupae were placed in plastic mini-greenhouses measuring $(288 \times 188 \times 170) \mathrm{mm}$ and further reared separately to the adult stage. Dead individuals were weighed to calculate mortality (weight of dead larvae per week) and were discarded. Live larvae were fed and placed in rearing box with an air temperature of $22-25^{\circ} \mathrm{C}$ and a relative humidity of 40 to $60 \%$. Sufficient fresh air was ensured by ventilating the air in the rearing area.

\subsection{Feed}

Wheat bran, ware potatoes, dried whey and polystyrene foam were used as feed for the experiments. The feeds were chosen so that the potatoes were representatives of the carbohydrate diet, whey as a representative of the protein diet and wheat bran as a control group. As a solution to the worldwide problem with plastics and the verification 
of biodegradation processes using the mealworms, a low-energy polystyrene foam was chosen as last feed. Wheat bran, ware potatoes and dried whey were purchased from a local commercial network. Polystyrene was purchased as a packaging material for food purposes.

Nutrition values of the feed were (per $100 \mathrm{~g}$ ):

Wheat bran/crude: energy value $1100 \mathrm{~kJ} / 262 \mathrm{kcal}$, fat $4.0 \mathrm{~g}$, of which saturated fatty acids $0.6 \mathrm{~g}$, carbohydrates $18.0 \mathrm{~g}$, of which sugars $0.5 \mathrm{~g}$, protein $17.0 \mathrm{~g}$, salt $0.01 \mathrm{~g}$. The producer was COUNTRY LIFE s.r.o., Beroun, the Czech Republic. The values were taken from the product packaging.

Dried whey: energy value $1484 \mathrm{~kJ} / 350 \mathrm{kcal}$, fat $1.5 \mathrm{~g}$, of which saturated fatty acids $1.0 \mathrm{~g}$, carbohydrates $72 \mathrm{~g}$, of which sugars $72 \mathrm{~g}$, fiber $6.2 \mathrm{~g}$, protein $12 \mathrm{~g}$, salt $3.2 \mathrm{~g}$. The producer was COUNTRY LIFE s.r.o., Beroun, the Czech Republic. The values were taken from the product packaging.

Raw ware potatoes-energy value $374 \mathrm{~kJ} / 89 \mathrm{kcal}$, fat $0.2 \mathrm{~g}$, of which saturated fatty acids $0.0 \mathrm{~g}$, carbohydrates $19 \mathrm{~g}$, of which sugars $1.0 \mathrm{~g}$, fiber $2.0 \mathrm{~g}$, protein $2.0 \mathrm{~g}$, salt $0.05 \mathrm{~g}$. The values were taken from the product packaging.

Polystyrene (PS), having the molecular formula [-CH $\left(\mathrm{C}_{6} \mathrm{H}_{5}\right) \mathrm{CH}_{2}$ - $] \mathrm{n}-$ where, although the nutritional value can generally be considered to be equal to zero, it was demonstrated to be otherwise by Yang et al. [16] after $\mathrm{CO}_{2}$ mineralization has been incorporated into lipids to contribute to the energy needs of mealworms. However, this is not a sufficient source of energy for the larvae [17].

\subsection{Determination of Nitrogen Content}

The total content of protein was determined using the Kjeldahl method (ISO 1871: 2009). Mineralization was the first phase in determining the total content of protein. A dried and homogenized sample weighing $1 \pm 0.0005 \mathrm{~g}$ was placed in cuvettes. Two tablets of selenium and $20 \mathrm{~mL}$ of $\mathrm{H}_{2} \mathrm{SO}_{4}$ (CAS 7664-93-9, Ing. Petr Švec-PENTA s.r.o., Prague, the Czech Republic) were further added to the cuvettes. Samples were mineralized at $420{ }^{\circ} \mathrm{C}$ for $105 \mathrm{~min}$.

Distillation, which was the second part of the process was performed using Kjeltec TM 2200 (FOSS, Denmark) for $4 \mathrm{~min}$ in 40\% NaOH (CAS 1310-73-2, Ing. Petr Švec-PENTA s.r.o., Prague, the Czech Republic), $2 \% \mathrm{H}_{3} \mathrm{BO}_{3}$ (CAS 10043-35-3, Ing. Petr Švec-PENTA s.r.o., Prague, the Czech Republic) and distilled water.

The last step of the process was titration with $0.2 \% \mathrm{H}_{2} \mathrm{SO}_{4}$ solution (CAS 7664-93-9, Ing. Petr Švec-PENTA s.r.o., Prague, the Czech Republic) using Tashiro indicator (CAS 64-17-5, Ing. Petr Švec-PENTA s.r.o., Prague, the Czech Republic).

The amount of crude protein was calculated by multiplying the content of detected nitrogen by a coefficient of 6.25. The conversion factor was selected according to valid Regulation (EU) No 1169/2011 [19]. However, this value increases the protein content of insects due to the presence of non-protein nitrogen. According to Janssen et al. [20], 4.76 is a specific conversion factor for mealybug larvae. Finke et al. [21] stated that part of the nitrogen is found in chitin polymers. The value should be more accurate after subtracting ADF-N from the total nitrogen content before multiplying by the conversion factor $[20,21]$. Nevertheless, a conversion factor of 6.25 was used because it allowed to compare the obtained values with other authors who used the same conversion factor [22-26].

The crude protein content was reported as an average value and standard error in $\mathrm{g} / 100 \mathrm{~g}$ DM was measured four times.

\subsection{Determination of Fat Content}

The Soxhlet method [27] was used for determining the fat content using Gerhardt Soxtherm SOX414 (C. Gerhardt GmbH \& Co., KG, Königswinter, Germany). A dried, homogenized and weighed sample (approximately $2 \mathrm{~g}$ with a weighing accuracy of $0.0001 \mathrm{~g}$ ) was put into extraction shell and extracted with $150 \mathrm{~mL}$ of n-heptane (CAS 142-82-5, LachNer, s.r.o., Neratovice, Czech Republic). The extraction time was set at $240 \mathrm{~min}$. Then, a 
sample was repeatedly weighted and dried at $103^{\circ} \mathrm{C}$ (dryer Venticell 111, BMT Medical Technology s.r.o., Brno, the Czech Republic) to a constant weight (the difference between two consecutive weighings was less than $10 \mathrm{mg}$ ). The fat content of the individual samples was determined three times by the gravimetric method and was reported as the arithmetic average value and standard error in $\mathrm{g} / 100 \mathrm{~g}$ DM [28].

\subsection{Determination of Fatty Acid Profile}

The esterification of lipids extracted form samples of insects via the Soxhlet extraction was performed according to the ISO 12966-2: 2011 standard using $0.25 \mathrm{M}$ methanolic $\mathrm{KOH}$ (test weight of fat for esterification was $0.5 \mathrm{~g}$ ).

Fatty acid methyl esters in the samples were analyzed using gas chromatography with flame ionization detector (FID) on GC-2010 (Shimadzu, Kyoto, Japan) using highly polar chromatographic column HP-88 (100 m $\times 0.25 \mathrm{~mm}, 0.2 \mu \mathrm{m}$ ) (Agilent Technologies, Santa Clara, CA, USA). Chromatographic conditions were as follows: spray volume $1 \mu \mathrm{L}$, spray temperature $250{ }^{\circ} \mathrm{C}$, split ratio $1: 100$, carrier gas nitrogen, temperature program $80{ }^{\circ} \mathrm{C} / 5 \mathrm{~min}, 200^{\circ} \mathrm{C} / 30 \mathrm{~min}, 250{ }^{\circ} \mathrm{C} / 15 \mathrm{~min}$.

Quantitative evaluation of fatty acid methyl ester (FAME) content in the samples was performed by using the method of internal and external standards. As inner standard, undecanoic acid methyl ester (Sigma Aldrich, St. Louis, MO, USA) was used for the inner normalization. FAME Mixture C4-C24 (Supelco, PA, USA) standard, which contained 37 selected fatty acids (FAs), was used as standard for the outer normalization. The individual FAMEs were converted to fatty acid esters in the evaluation and the individual proportion was expressed in $\mathrm{g} / \mathrm{kg}$ dry matter. [28] The fatty acid profile was measured four times.

\subsection{Statistical Evaluation of Data}

Values obtained from the determination of nutrients were expressed as the arithmetic average \pm standard error. Excel program (Microsoft Corporation, Redmond, WA, USA) was used for basic calculations. STATISTICA CZ version 12 (StatSoft, Inc., Tulsa, OK, USA) was used for statistical data analysis. The homogeneity of the variance of the sets was tested using the Brown-Forsythe test of homogeneity of variance. Due to the methodology, the normal character of the files was assumed. If the conditions for the ANOVA calculation were met, a Scheffe post-hoc test of significant differences and/or division into homogeneous groups was performed. If the ANOVA method could not be used, a nonparametric Kruskal-Walllis test $(\alpha=0.05)$ and multiple comparisons of $p$ values (two-sided) $(\alpha=0.05)$ were performed based on the Mann-Whitney U test.

\section{Results and Discussion}

\subsection{Influence of Feed on Life Cycle}

The first phase of the experiment yielded knowledge and data on the life cycle of the powdery mildew, which are summarized in Table 1 and Figure 1.

Table 1. Number of larvae at the beginning of the first phase of the experiment, pupae and adults formed during the experiment and the sum of live individuals at the end of the first phase of the experiment.

\begin{tabular}{cccccc}
\hline Feed & Larvae & Pupae & Adults & Individuals & Mortality \\
\hline & (0. Week) & $\mathbf{( - )}$ & $\mathbf{( - )}$ & $\mathbf{( 2 1 . ~ W e e k )}$ & $\mathbf{( \% )}$ \\
\hline Wheat bran & 20 & 13 & 10 & 11 & 45 \\
Dried whey & 20 & 5 & 3 & 12 & 40 \\
Ware potatoes & 20 & 6 & 6 & 15 & 25 \\
Polystyrene & 20 & 5 & 3 & 5 & 75 \\
\hline
\end{tabular}




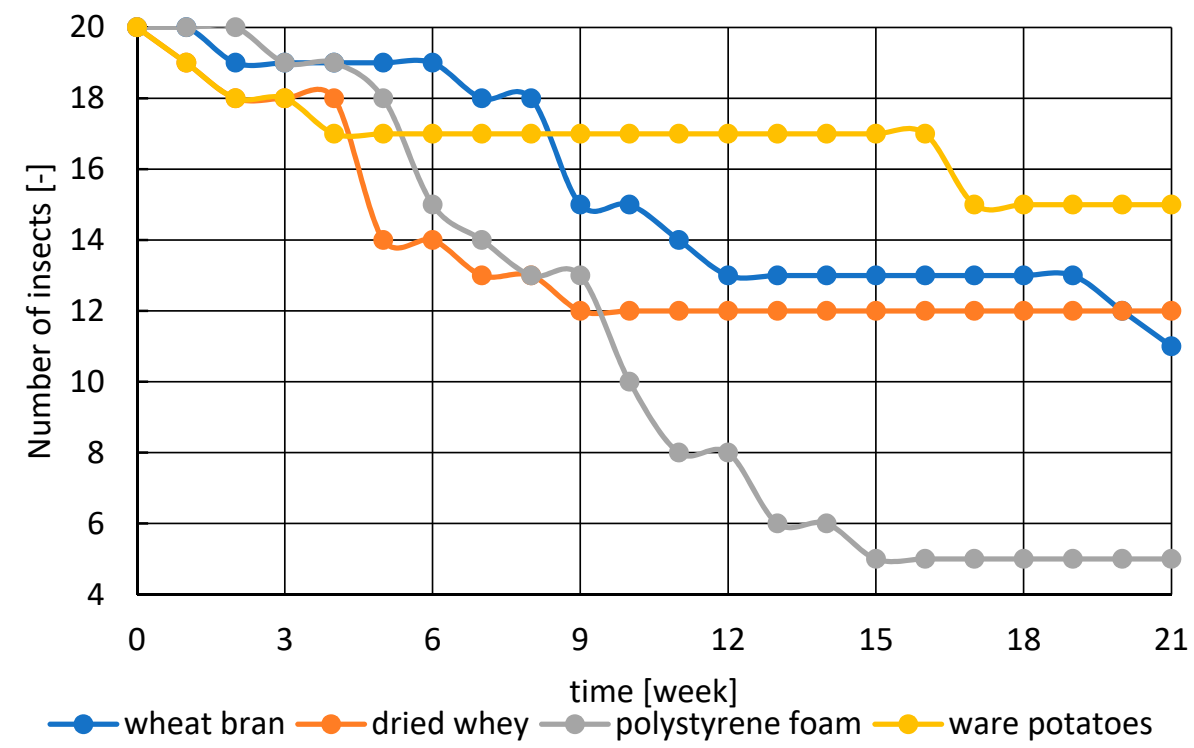

Figure 1. Number of live insects (sum of larvae, pupae and adults) during the first phase of rearing.

The Table 1 shows the high mortality of mealworms fed with polystyrene foam, which was caused by almost zero nutritional value. The group fed potatoes, on the other hand, had the lowest mortality. There was also no death of the pupa in this group and there were no defects and problems in the development from the pupa stage to higher developmental stages.

Mortality in the groups fed by wheat bran and dried whey was relatively high, but lower than that in the group fed by polystyrene foam and ware potatoes. Bran food had a positive effect on life development and most accelerated the development of an individual into an adult. This is an important factor for the resulting rearing gain, as it is the higher speed of the life cycle that is characteristic of the farmer [1,29]. However, due to the high number of adults, the mortality rate may be slightly skewed.

Yang S. [30] states that cannibalism is caused by hunger, and the darkling beetle decides to do so only when it is forced to do so. From this point of view, it is interesting that groups that were fed wheat bran and dried whey experienced occasional cannibalism. Cannibalism was not observed in the groups fed by potatoes but also with polystyrene. It can be assumed because some types of feed (in the present study, polystyrene) can weaken the larvae by losing aggression towards other larvae.

In the second phase of the experiment, a larger group ( $500 \mathrm{~g}$ of larvae at the beginning) was tested for 5 weeks. The number of pupae formed and hatched individuals of the second phase of the experiment is shown in Figure 2. Similarly to the first phase of the experiment, the changes in life development were again the greatest in the bran-fed group. Compared to the other groups being fed a different diet, the bran-fed group had both a higher increase in the number of pupae formed $(3.2 \times$ compared to the dried whey, $2.7 \times$ ware potatoes, $6.1 \times$ polystyrene foam) and a higher increase in the number of adults formed ( $5.4 \times$ compared to dried whey, $35.7 \times$ ware potatoes, $21.4 \times$ with polystyrene foam) against the other groups. Each feed had a reduction in the number of individuals since a certain week. Darkling beetle can accelerate its development if rearing conditions improve. However, the acceleration is limited in time and therefore it is advantageous to change the feed in order to achieve the highest rearing efficiency. In the case of dried whey, there was an error in the feeding in the fifth week of the measurement (the feed was moistened), therefore, this value might have been slightly skewed. The smallest number of helmets and adults formed was recorded for polystyrene foam. A similar number of adults was recorded for ware potatoes, although the number of larvae was significantly higher. Individuals were unable to cross the boundary between the hood and the adult. Although there could 
have been many causes, the authors hypothesized the lack of nutrients in the feed necessary to complete development.

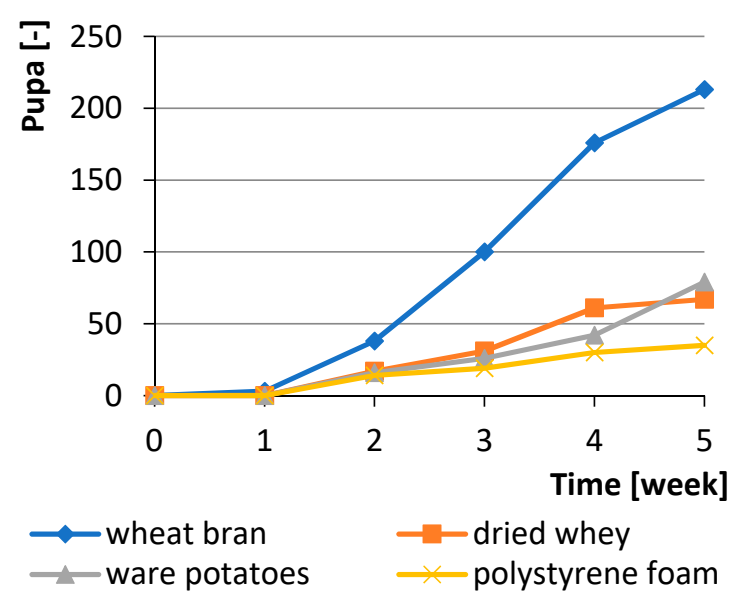

(a)

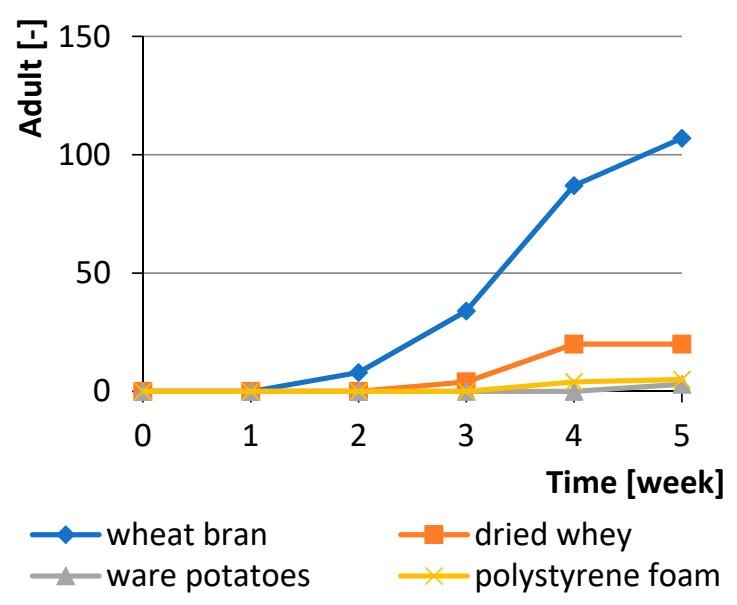

(b)

Figure 2. Number of individuals formed since the beginning of the second phase of experiment (a) pupa; (b) adults.

Although the fastest development of individuals was found in the bran-fed group, the highest mortality of $18 \mathrm{~g}$ dead larvae/week was also found in this group in the second week from the beginning of the second phase of the experiment. In the following weeks, there was a steady decrease in mortality to $5 \mathrm{~g}$ dead larvae/week at the end of the experiment. This trend was in contrast to the mortality in the polystyrene-fed group, where, in the first two weeks of the second phase of the experiment, the larval mortality was only $1.4 \mathrm{~g}$ dead larvae/week, and from the third week, it started to increase similarly to the first part of the experiment to $8 \mathrm{~g}$ dead larvae/week at the end of the experiment. One possible explanation was in the reduction in cannibalism among larvae, as mentioned earlier. In the groups fed whey and potatoes, mortalities of $14.3 \mathrm{~g}$ dead larvae/week (whey) and $13.3 \mathrm{~g}$ dead larvae/week (potatoes) were recorded in the first week of the second phase of the experiment. In the second week, a decrease in mortality to $6.5 \mathrm{~g}$ dead larvae/week was observed in the group fed with potatoes, followed by an increase to $15 \mathrm{~g}$ dead larvae/week at the end of the experiment. In the group fed with whey, there was a similar decrease in mortality as in the group fed with potatoes, but the lowest value of $10 \mathrm{~g}$ dead larvae/week was reached in the third week from the beginning of phase 2 of the experiment. This was followed by an increase to $17 \mathrm{~g}$ dead larvae/week.

In both phases of the experiment, the weight of the samples was gradually reduced by regular sampling of pupae, adults and dead individuals. However, weight was determined only in larvae and in found dead individuals. For this reason, it was not possible to compare the results with other authors $[16,17,31-34]$, who have currently focused mainly on the biodegradation of plastics in various insect species. The studies [35] on waste biodegradation by Tenebrio molitor) described the weight loss of groups of larvae in individual types of plastics after 21 days from $-15 \%$ to $-19 \%$. There were also losses in this work. In the second part of the experiment, after 21 days, however, they were significantly higher- $-41 \%$. However, this value was distorted by the above-mentioned sampling of pupae and adults from the sample. These results were not consistent with, for example, Nukmal et al. [36], which demonstrated a significant increase in weight from an initial larval weight of $59.14 \pm 1.64 \mathrm{mg}$ to a final larval weight of $188.0 \pm 2.94 \mathrm{mg}$ for Expanded Polystyrene (EPS) and from $60.21 \pm 1.96 \mathrm{mg}$ to $183.75 \pm 2.23$ for Extruded Polystyrene (XPS). 


\subsection{Influence of Feed on Crude Protein and Fat Content}

After the end of the rearing in the second phase of the experiment, insect samples were taken from individual rears to determine selected nutritional values. In addition, excrement samples were taken from all groups except for excrement in the bran-fed group, where it was not possible to isolate excrement for technological reasons. The values of crude protein and fat content in larvae and excrement are given in Table 2.

Table 2. Content of nitrogenous substances and fat $[\mathrm{g} / 100 \mathrm{~g} \mathrm{DM}]$ in larvae and excrements for various feeds after five weeks of rearing.

\begin{tabular}{ccccc}
\hline Feed & \multicolumn{2}{c}{ Crude Protein } & \multicolumn{2}{c}{ Fat } \\
& $\begin{array}{c}\text { Larvae } \\
\mathbf{M} \pm \mathbf{S E}\end{array}$ & $\begin{array}{c}\text { Excrement } \\
\mathbf{M} \pm \mathbf{S E}\end{array}$ & $\begin{array}{c}\text { Larvae } \\
\mathbf{M} \pm \mathbf{S E}\end{array}$ & $\begin{array}{c}\text { Excrement } \\
\mathbf{M} \pm \mathbf{S E}\end{array}$ \\
\hline Wheat bran & $53.6^{\mathrm{a}} \pm 0.4$ & - & $37.1^{\mathrm{d}} \pm 0.5$ & - \\
Dried whey & $59.0^{\mathrm{b}} \pm 0.6$ & $50^{\mathrm{a}} \pm 3$ & $25.7^{\mathrm{b}} \pm 1.2$ & $6.9^{\mathrm{a}} \pm 0.6$ \\
Ware potatoes & $54.9^{\mathrm{a}} \pm 0.3$ & $46.7^{\mathrm{a}} \pm 0.4$ & $31.2^{\mathrm{c}} \pm 0.4$ & $7.4^{\mathrm{a}} \pm 0.8$ \\
Polystyrene & $69.77^{\mathrm{c}} \pm 0.09$ & $82.68^{\mathrm{b}} \pm 0.08$ & $13.45^{\mathrm{a}} \pm 0.11$ & $5.1^{\mathrm{a}} \pm 0.5$ \\
\hline
\end{tabular}

Note: $\mathrm{M}$-arithmetic average (mean), SE—standard error, a, b, c, d-division into homogeneous groups (Scheffe's test; alpha $=0.05)$.

The comparison of fat and nitrogen content in larvae was performed using ANOVA and Scheffe's test. For fat (ANOVA; $N=12 ; \mathrm{F}=262.99 ; p<0.001$ ), a statistically significant difference was found between all groups of feeds; in the case of nitrogenous substances (ANOVA; $\mathrm{N}=16 ; \mathrm{F}=270.29 ; p<0.001$ ), a statistically significant difference was found between all groups of feeds except for the comparison of bran-potatoes feeds.

For excrement, comparisons could be made by ANOVA only for fat $(\mathrm{N}=12 ; \mathrm{F}=4.25$; $p=0.071$ ), where no statistically significant differences were found between the groups. Nevertheless, it is possible to trace a trend where the fat content in the excrement is proportional to the fat content in the body of the larvae. The fat content of the excrement was higher than reported by Ravzanaadii et al. [37] (1.3\% for wheat bran as main feed). This allowed the use of excrement as a supplement to the source of organic matter in the substrates. It was not possible to use the ANOVA method for the comparison of nitrogenous substances in excrements due to non-compliance with the assumptions for this method, therefore, the Kruskal-Wallis test $(\mathrm{N}=12 ; \mathrm{H}=7.38 ; p=0.025)$ was used for the comparison. Although $p<0.05$ was found in this test, subsequent multiple two-tailed comparisons of $p$ values did not show a statistically significant difference between the groups. When comparing the polystyrene-fed group with the other groups, the calculated $p$-value was just above $0.05(p=0.056)$, so it can be assumed that the Kruskal-Wallis test captured this difference. The values of the content of nitrogenous substances in the excrement again followed the content of nitrogenous substances in the body of the larvae. The values found were higher than those determined by Ravzanaadii et al. [37] (18.5\%).

When consuming only polystyrene foam $\left(\left[-\mathrm{CH}\left(\mathrm{C}_{6} \mathrm{H}_{5}\right) \mathrm{CH}_{2}-\right] \mathrm{n}\right)$, a significant proportion of nitrogenous substances was found both in larval bodies and especially in excrements. The question was in the presence of these substances in the case of feeding this material. Cannibalism and biological functions in the larval body, which have not yet been fully elucidated, were likely to play a role.

The use of polystyrene foam as feed was also addressed by Zielińska et al. [17], which gives a protein content of $(51.93 \pm 0.98) \%$ for Styrofoam and $(37.06 \pm 0.92) \%$ for conventional feed at a conversion factor of 4.76 . If a coefficient of 6.25 were applied, the values would be in accordance with the measured values $(68.19 \%$ and $48.66 \%)$. In the fat content, Zielińska et al. [17] records a significant decrease in value from $(43.74 \pm 0.77) \%$ in the control group to $(24.05 \pm 0.55) \%$ in the Styrofoam-fed group. There was also a significant decrease in this work. Different values could be due to the use of a different type of solvent.

Raheem et al. [38] reported nutritional values for TM ranging from $44.8 \%$ to $50.1 \%$ DM protein content. Bednářová [39] also records a nitrogen content of common feed of 
(50.9 \pm 7.7)\%, Ravzanaadii et al. [37] 46.44\% and Finke [40] 49.1\%. Ghaly and Alkoaik [41] recorded a protein content of up to 63.3\% DM (63.31-68.87). Van Broekhoven et al. [11] reports from $45.1 \%$ to $48.6 \%$ depending on the feed. The values determined in this work outside the sample fed with polystyrene are in accordance with these values.

The fat content of TM larvae was reported by Raheem et al. [38] from 39.1\% to 40.5\% depending on the diet. High protein values of $43.1 \%$ or $43.7 \%$ were also reported by Rumpold and Schlüter [42] and Zielińska et al. [17]. These fat content values were higher than reported by Bednářová et al. [39] (36.1\%) or Finke [40] (35.0\%). In contrast, the content of $6.4 \%$ [43], $8.9 \%$ [44] or $14.6 \%$ [8] were reported as one of the lowest values of fat content. In accordance with the period of starvation, the fat content may further decrease [8]. Depending on the feed, Broekhoven et al. [11] reported a range from 18.9 to $27.6 \%$. Adamkova et al. [8] in their study monitored not only feed but also the rearing temperature, and the fat content was in the range of 16.6 to $29.5 \%$. The values found in this work are in accordance with the above values.

\subsection{Influence of Feed on Fatty Acid Profile}

When determining the fat content, the fatty acid profile was also determined. The results are shown for the larvae in Table 3, which show the highest values of fatty acids (FA) for oleic acid (C18:1Z), linoleic acid (C18:2), palmitic acid (C16:0), myristic acid (C14:0), stearic acid (C18:0) and palmitoleic acid (C16:1). These acids made up the majority of all measured fatty acids.

Table 3. Content of selected fatty acids (FA) $[\mathrm{g} / \mathrm{kg} \mathrm{DM}]$ in larvae for various feeds after five weeks of rearing.

\begin{tabular}{|c|c|c|c|c|}
\hline \multirow[t]{2}{*}{ Fatty Acid } & \multicolumn{4}{|c|}{ Feed } \\
\hline & $\begin{array}{c}\text { Wheat Bran } \\
\mathbf{M} \pm \mathbf{S E}\end{array}$ & $\begin{array}{l}\text { Dried Whey } \\
\qquad \mathbf{M} \pm \mathbf{S E}\end{array}$ & $\begin{array}{l}\text { Ware Potatoes } \\
\qquad \mathbf{M} \pm \mathbf{S E}\end{array}$ & $\begin{array}{l}\text { Polystyrene } \\
\mathbf{M} \pm \mathbf{S E}\end{array}$ \\
\hline $\mathrm{C} 10$ & $0.0342^{\mathrm{a}} \pm 0.0017$ & $0.043^{\mathrm{a}, \mathrm{b}} \pm 0.004$ & $0.050^{b} \pm 0.003$ & $0.023^{c} \pm 0.003$ \\
\hline C12 & $0.83^{c} \pm 0.06$ & $0.633^{a} \pm 0.019$ & $0.521^{\mathrm{a}} \pm 0.016$ & $0.242^{b} \pm 0.010$ \\
\hline $\mathrm{C} 13$ & $0.162^{c} \pm 0.008$ & $0.130^{\mathrm{a}} \pm 0.005$ & $0.138^{a} \pm 0.004$ & $0.079^{b} \pm 0.007$ \\
\hline $\mathrm{C} 14$ & $10.4^{\mathrm{c}} \pm 0.5$ & $8.6^{a} \pm 0.3$ & $8.3^{\mathrm{a}} \pm 0.3$ & $3.59^{b} \pm 0.15$ \\
\hline C15 & $0.248^{a} \pm 0.007$ & $0.145^{c} \pm 0.008$ & $0.247^{\mathrm{a}} \pm 0.009$ & $0.106^{b} \pm 0.008$ \\
\hline C16 & $45.1^{\mathrm{d}} \pm 1.0$ & $24.1^{\mathrm{b}} \pm 0.8$ & $34.9^{\mathrm{c}} \pm 1.0$ & $9.7^{\mathrm{a}} \pm 0.5$ \\
\hline $\mathrm{C} 17$ & $0.525^{\mathrm{a}, \mathrm{b}} \pm 0.019$ & $0.461^{\mathrm{a}} \pm 0.013$ & $0.59^{b} \pm 0.04$ & $0.260^{\mathrm{c}} \pm 0.011$ \\
\hline $\mathrm{C} 18$ & $6.39^{a} \pm 0.06$ & $4.92^{\mathrm{c}} \pm 0.14$ & $6.10^{a} \pm 0.17$ & $2.17^{b} \pm 0.10$ \\
\hline $\mathrm{C} 20$ & $0.258^{c} \pm 0.010$ & $0.180^{\mathrm{a}} \pm 0.005$ & $0.191^{\mathrm{a}} \pm 0.008$ & $0.087^{b} \pm 0.006$ \\
\hline C14:1 & $0.038^{b} \pm 0.004$ & $0.028^{\mathrm{a}, \mathrm{b}} \pm 0.003$ & $0.021^{b} \pm 0.003$ & $0.009^{c} \pm 0.001$ \\
\hline C16:1 & $3.82^{\mathrm{a}} \pm 0.04$ & $3.84^{\mathrm{a}} \pm 0.17$ & $4.61^{\mathrm{c}} \pm 0.13$ & $1.30^{b} \pm 0.06$ \\
\hline C18:1Z & $117.3^{\mathrm{a}} \pm 1.0$ & $98^{c} \pm 4$ & $126^{\mathrm{a}} \pm 4$ & $41.9^{b} \pm 1.9$ \\
\hline C20:1 & $1.43^{c} \pm 0.04$ & $0.381^{\mathrm{a}} \pm 0.014$ & $0.92^{b} \pm 0.03$ & $0.321^{\mathrm{a}} \pm 0.014$ \\
\hline C18:2 & $67.5^{\mathrm{d}} \pm 1.6$ & $38.2^{b} \pm 1.2$ & $52.9^{c} \pm 1.5$ & $20.5^{\mathrm{a}} \pm 0.9$ \\
\hline C18:3 & $0.233^{d} \pm 0.006$ & $0.110^{b} \pm 0.009$ & $0.197^{c} \pm 0.010$ & $0.062^{\mathrm{a}} \pm 0.008$ \\
\hline C20:2 & $0.099^{b} \pm 0.005$ & $0.051^{\mathrm{a}} \pm 0.006$ & $0.083^{b} \pm 0.007$ & $0.040^{\mathrm{a}} \pm 0.009$ \\
\hline Sum of saturated FA & 63.9584 & 39.2622 & 51.0840 & 16.2772 \\
\hline Sum of monoenoic FA & 122.5961 & 102.2514 & 131.6951 & 43.48601 \\
\hline Sum of polyenoic FA & 67.8129 & 38.35526 & 53.18262 & 20.55448 \\
\hline Total FA Content & 254.3675 & 179.8689 & 235.9618 & 80.31778 \\
\hline
\end{tabular}

Note: ${ }^{a, b, c, d}$-division into homogeneous groups (Scheffe's test; alpha $\left.=0.05\right)$. Abbreviations: M—arithmetic average (mean), SE—standard error, FA—fatty acid.

A similar composition of the fatty acid profile was found by Finke [45], Ravzanaadii et al. [37], Zielinska et al. [23] or Dreassi et al. [14], who also report oleic acid (C18:1) as the most abundant fatty acid in the larval body. Although the authors normally report an oleic acid content in the range of $41-46 \%$ of all the fatty acids, this article shows an increase in oleic acid content of up to $54 \%$ when fed with whey and $53 \%$ when fed on ware potatoes. This was followed by linoleic acid (C18:2), which is usually in the range of $27-31 \%$ in the literature. The content of $21-27 \%$ was measured in the article, depending on the type of 
food. Dreassi et al. [14], however, reported a content of linoleic acid of only 19\% and rank the acid up to third place after palmitic acid (C16:0) with a content of $19.4 \%$. Palmitic acid (C16:0) is ranked third in the cited authors and in the measured results. Its content is described by other authors in the range of 16.7 to $19.4 \%$. This does not correspond to the results reported in this work, where the palmitic acid content was determined to be lower (12.1-17.7\% depending on the type of feed). The results are followed by myristic acid (C14:0), stearic acid (C18:0) and palmitoleic acid (C16:1), the content of which is in percentage units. Other fatty acids were usually determined by the authors and measured results below $1 \%$. An exception was linolenic acid (C18:3), whose content ranged from $0.3 \%$ [14] to $1.6 \%$ [23]. Ravzanaadii et al. [37] stated a value of $1.4 \%$, and from Finke [45], it is possible to obtain a value of $1.1 \%$ after recalculation. The values are not in accordance with the measured results, where lower values of linolenic acid content were determined.

The highest content of fatty acids was detected in a sample of mealworm larvae fed with bran $(254.4 \mathrm{~g} / \mathrm{kg}$ dry matter). This was followed by larvae fed with potatoes $(236.0 \mathrm{~g} / \mathrm{kg}$ dry matter) and whey $(179.9 \mathrm{~g} / \mathrm{kg}$ dry matter). The lowest value of $80.3 \mathrm{~g} / \mathrm{kg}$ dry matter was measured in a sample fed with polystyrene foam and was more than $68 \%$ smaller than in larvae fed with bran. This value corresponds to the trend of the fat content in the sample.

In the percentage of the determined FA, mostly monoenoic (MC) was present, and their total content ranged from $48.2 \%$ in bran-fed larvae to $56.8 \%$ in whey-fed larvae. The sums of saturated FA and polyene FA were represented by a similar proportion. For polyene $\mathrm{FA}$, the sum ranges from $21.3 \%$ (whey) to $26.7 \%$ (bran). It was interesting to find that the larvae of polystyrene $(54.1 \%)$ and polyene $(25.6 \%)$ of the polystyrene-fed larvae were among the highest. On the contrary, the content of saturated FA $(20.3 \%)$ is the smallest of all feeds. This composition is very nutritionally suitable for humans. For other feeds, the range of saturated FA ranged from $21.6 \%$ (potatoes) to $25.1 \%$ (bran).

According to the Food and Agriculture Organization's (FAO) [46] nutritional recommendations, a suitable ratio of saturated, monoene and polyene fatty acids is about 1:(1.3-1.8):(0.6-1.1). This ratio is calculated for a total fat intake of $35 \%$ of energy and $1 \%$ trans-fatty acid of energy.

Ratios were created from the measured data. The ratio was 1.0:1.9:1.1 for bran-fed larvae, 1.0:2.6:1.0 for whey and potato feed and 1.0:2.7:1.3 for polystyrene foam feed. From the point of view of human nutrition, it is possible to determine bran as the most optimal feed for insects according to the difference in conditions. Although the larvae have a higher proportion of unsaturated fatty acids, their values can be adjusted, and in the case of further research, equality with nutritional recommendations can be achieved.

The fatty acid profiles of excrement of farmer's larvae fed with different types of feed are given in Table 4 . The proportion of fatty acids in the excrements relative to the fatty acid content in the body $\left(\mathrm{FAD}=\left(\mathrm{FA}_{\mathrm{exc}} / \mathrm{FA}_{\mathrm{lar}}\right) * 100 \%\right)$ was usually between about 6 and $20 \%$ (It is assumed that the smaller this ratio, the more it is necessary to supply the given fatty acid in another type (addition) of feed for a given feed). The exception was saturated C10 acid, where the proportion was $84 \%$ for polystyrene and $76 \%$ for whey but decreased to $26 \%$ for potatoes. A similar trend was found, for example, in the case of C17 or C18 acids. On the contrary, saturated C20 acid exhibited the opposite trend-for potatoes, the share was $83 \%$, but for polystyrene, it decreased to $63 \%$ and for whey to $59 \%$. For C16:1, C18:1 and C20:1 monoenoic fatty acids, the proportion of potatoes and polystyrene is approximately in the range of 9 to $12 \%$. For whey, these proportions were higher (13-22\%). In the case of polyenoic fatty acids in potatoes, the proportions were smaller (11-14\%) than in other feeds $(12-30 \%)$, but the absolute total amount of polyenoic fatty acids was the highest $(6.1 \mathrm{~g} / \mathrm{kg})$. 
Table 4. Content of selected fatty acids (FA) $[\mathrm{g} / \mathrm{kg} \mathrm{DM}]$ in excrement for different feeds after five weeks of rearing and the ratio of this content $\left(\mathrm{FA}_{\mathrm{exc}}\right)$ to the fatty acid content in the body of larvae $\left(\left(\mathrm{FA}_{\mathrm{lar}}\right)-\left(\mathrm{FAD}=\left(\mathrm{FA}_{\mathrm{exc}} / \mathrm{FA}_{\mathrm{lar}}\right) * 100 \%\right)\right.$.

\begin{tabular}{|c|c|c|c|c|c|c|}
\hline \multirow{3}{*}{ Fatty Acid } & \multicolumn{6}{|c|}{ Feed } \\
\hline & \multicolumn{2}{|c|}{ Dried Whey } & \multicolumn{2}{|c|}{ Ware Potatoes } & \multicolumn{2}{|c|}{ Polystyrene } \\
\hline & $\begin{array}{c}\mathrm{M} \pm \mathrm{SE} \\
{[\mathrm{g} / \mathrm{kg} \mathrm{DM}]}\end{array}$ & $\begin{array}{c}\text { FAD } \\
{[\%]}\end{array}$ & $\begin{array}{c}\mathrm{M} \pm \mathrm{SE} \\
{[\mathrm{g} / \mathrm{kg} \mathrm{DM}]}\end{array}$ & $\begin{array}{c}\text { FAD } \\
{[\%]}\end{array}$ & $\begin{array}{c}\mathrm{M} \pm \mathrm{SE} \\
{[\mathrm{g} / \mathrm{kg} \mathrm{DM}]}\end{array}$ & $\begin{array}{c}\text { FAD } \\
{[\%]}\end{array}$ \\
\hline $\mathrm{C} 10$ & $0.033^{b} \pm 0.005$ & 76.4 & $0.013^{a} \pm 0.003$ & 26.0 & $0.0194^{a} \pm 0.0015$ & 84.5 \\
\hline $\mathrm{C} 12$ & $0.065^{b} \pm 0.003$ & 10.3 & $0.034^{\mathrm{a}} \pm 0.002$ & 6.5 & $0.024^{a} \pm 0.006$ & 9.9 \\
\hline $\mathrm{C} 13$ & $0.013^{a} \pm 0.003$ & 10.3 & $0.011^{\mathrm{a}} \pm 0.003$ & 8.1 & $0.012^{\mathrm{a}} \pm 0.002$ & 14.6 \\
\hline $\mathrm{C} 14$ & $0.770^{c} \pm 0.005$ & 9.0 & $0.530^{\mathrm{b}} \pm 0.006$ & 6.4 & $0.198^{a} \pm 0.010$ & 5.5 \\
\hline C15 & $0.025^{a} \pm 0.003$ & 17.6 & $0.023^{\mathrm{a}} \pm 0.006$ & 9.3 & $0.012^{\mathrm{a}} \pm 0.005$ & 11.5 \\
\hline $\mathrm{C} 16$ & $3.62^{c} \pm 0.04$ & 15.0 & $3.31^{\mathrm{b}} \pm 0.04$ & 9.5 & $1.03^{\mathrm{a}} \pm 0.05$ & 10.7 \\
\hline $\mathrm{C} 17$ & $0.310^{c} \pm 0.008$ & 67.3 & $0.224^{b} \pm 0.008$ & 38.0 & $0.160^{\mathrm{a}} \pm 0.007$ & 61.4 \\
\hline C18 & $1.36^{\mathrm{c}} \pm 0.03$ & 27.7 & $1.046^{b} \pm 0.013$ & 17.2 & $0.64^{\mathrm{a}} \pm 0.05$ & 29.4 \\
\hline $\mathrm{C} 20$ & $0.106^{b} \pm 0.008$ & 58.9 & $0.159^{c} \pm 0.008$ & 83.0 & $0.054^{\mathrm{a}} \pm 0.010$ & 62.6 \\
\hline C14:1 & $0.0075^{a} \pm 0.0007$ & 26.7 & ND & 0.0 & $0.009^{a} \pm 0.003$ & 96.8 \\
\hline C16:1 & $0.523^{b} \pm 0.006$ & 13.6 & $0.511^{b} \pm 0.010$ & 11.1 & $0.126^{\mathrm{a}} \pm 0.015$ & 9.7 \\
\hline C18:1Z & $15.07^{\mathrm{b}} \pm 0.19$ & 15.4 & $15.69^{b} \pm 0.14$ & 12.5 & $4.7^{\mathrm{a}} \pm 0.3$ & 11.2 \\
\hline C20:1 & $0.085^{b} \pm 0.012$ & 22.3 & $0.117^{\mathrm{b}} \pm 0.007$ & 12.7 & $0.031^{\mathrm{a}} \pm 0.009$ & 9.6 \\
\hline C18:2 & $5.84^{\mathrm{b}} \pm 0.06$ & 15.3 & $6.04^{b} \pm 0.07$ & 11.4 & $2.44^{\mathrm{a}} \pm 0.12$ & 11.9 \\
\hline C18:3 & $0.013^{\mathrm{a}} \pm 0.003$ & 11.7 & $0.025^{\mathrm{a}} \pm 0.004$ & 12.8 & $0.010^{\mathrm{a}} \pm 0.007$ & 16.8 \\
\hline C20:2 & $0.016^{\mathrm{a}} \pm 0.003$ & 30.5 & $0.012^{\mathrm{a}} \pm 0.003$ & 14.1 & $0.010^{\mathrm{a}} \pm 0.003$ & 23.9 \\
\hline Sum of saturated FA & 6.3 & 16.1 & 5.4 & 10.5 & 2.2 & 13.2 \\
\hline Sum of monoenoic FA & 15.7 & 15.3 & 16.3 & 12.4 & 4.9 & 11.2 \\
\hline Sum of polyenoic FA & 5.9 & 15.3 & 6.1 & 11.4 & 2.5 & 11.9 \\
\hline Total FA Content & 27.9 & 15.5 & 27.7 & 11.8 & 9.5 & 11.8 \\
\hline
\end{tabular}

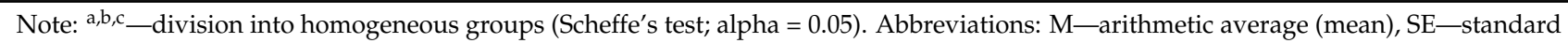
error, FA—fatty acid.

After calculating the total sums of individual types of fatty acids, the results showed the smallest share was in the sample fed potatoes (10-12\%), then in polystyrene (11-13\%) and the highest was in the sample fed whey (15-16\%). However, the absolute values were the smallest values for samples fed with polystyrene (approximately $3 \times-4 \times$ less than for other feeds). Although the content of nutrients ingested from the feed was greatly reduced, the excretion of fatty acids continued. This supported the results reported by Yang et al. [16] that after the mineralization of polystyrene in the larval intestine, part is incorporated into lipids. The total fatty acid content of the samples fed with whey and potatoes was approximately the same. The results in Table 4 show a slight increase in the absolute values of saturated fatty acids in the samples fed with whey than in the samples fed with potatoes. On the contrary, in the samples fed with potatoes, there were increased values in the total content of monoene and polyene fatty acids.

The ratio of the content of the major fatty acids remained the same in both larvae and excrement. The measured results are confirmed by Ravzanaadii et al. [37], which comes to a similar conclusion.

The measured results of the fatty acid profile in mealworm larvae showed that the fatty acid profiles in both larvae and excrement can be adjusted by changing the feed, and it is possible to increase the value of essential fatty acids.

\section{Conclusions}

The quality of rearing of the larvae of Tenebrio molitor is a basic indicator of the quality and safety of edible insects. This study looked at the effect of feed on life cycle speed, mortality and the content of fats, fatty acids and nitrogenous substances. The results showed that darkling larvae grow best on wheat bran, while other types of feed slowed down development, with significantly higher mortality and fat loss. When determining the total fatty acid content, the most detected was $254.4 \mathrm{~g} / \mathrm{kg}$ DM in bran-fed larvae. At least $80.3 \mathrm{~g} / \mathrm{kg}$ DM was determined in larvae fed polystyrene, where the development 
cycle was also very slow. On the contrary, the advantage was the increased amount of nitrogenous substances both in the larvae and in their excrement. This indicated the need to combine feeds appropriately in the event of the possible biodegradation of plastics using mealybug larvae. The study also showed the effect of feed not only on larvae but also demonstrated the impact of feed on excrement, which can be used as an input material in other agricultural applications.

Author Contributions: Conceptualization, A.A. and I.K.; methodology, M.M.; software, J.M. (Jiří Matyáš); validation, M.M., M.B. and Z.V.; formal Analysis, R.V. (Robert Vícha); investigation, J.M. (Jiří Matyáš); resources, R.V. (Radek Vychodil); data curation, M.A.; writing—original draft preparation, A.A. and M.A.; writing—review and editing, J.M. (Jiří Mlček); visualization, M.A.; supervision, J.M. (Jiří Mlček); project administration, M.B.; funding acquisition, J.M. (Jiří Mlček). All authors have read and agreed to the published version of the manuscript.

Funding: This article was supported by the internal grant of TBU in Zlín (No. IGA/FT/2021/008) and project BUT in Brno (FEKT-S-20-6215). This research was also funded by the Ministry of Education, Youth and Sports of the Czech Republic-DKRVO (RP/CPS/2020/006).

Institutional Review Board Statement: Not applicable.

Informed Consent Statement: Not applicable.

Data Availability Statement: New research data were presented in this contribution.

Conflicts of Interest: The authors declare no conflict of interest.

\section{References}

1. van Huis, A.; van Itterbeeck, J.; Klunder, H.; Mertens, E.; Halloran, A.; Muir, G.; Vantomme, P. Edible Insects: Future Prospects for Food and Feed Security; FAO: Rome, Italy, 2013; p. 187.

2. Mancini, S.; Moruzzo, R.; Riccioli, F.; Paci, G. European consumers' readiness to adopt insects as food. A review. Food Res. Int. 2019, 122, 661-678. [CrossRef]

3. Chow, C.-Y.; Riantiningtyas, R.R.; Sørensen, H.; Frøst, M.B. School children cooking and eating insects as part of a teaching program-Effects of cooking, insect type, tasting order and food neophobia on hedonic response. Food Qual. Prefer. 2020, 87, 104027. [CrossRef]

4. Garino, C.; Zagon, J.; Braeuning, A. Insects in food and feed-allergenicity risk assessment and analytical detection. EFSA J. 2019, 17, e170907.

5. European Commission Website. Food Safety. Approval of First Insect as Novel Food. Available online: https: / / ec.europa.eu/ food/safety/novel-food/authorisations / approval-first-insect-novel-food_en (accessed on 12 October 2021).

6. Ipiff. The International Platform of Insects for Food and Feed. Available online: https://ipiff.org/wp-content/uploads/2019/12/ IPIFF-researchpriorities-HorizonEurope.pdf (accessed on 12 October 2021).

7. Wu, S.; Lin, H.; Li, M.; Tang, X. Determination of some important technique parameters in the course of breeding Tenebrio molitor. J. Econ. Anim. 2009, 13, 28-31.

8. Adámková, A.; Mlček, J.; Adámek, M.; Borkovcová, M.; Bednářová, M.; Hlobilová, V.; Knížková, I.; Juríková, T. Tenebrio molitor (Coleoptera: Tenebrionidae)—Optimization of Rearing Conditions to Obtain Desired Nutritional Values. J. Insect Sci. 2020, 20, 24. [CrossRef] [PubMed]

9. Morales-Ramos, J.A.; Rojas, M.G.; Shapiro-Ilan, D.I.; Tedders, W.L. Developmental Plasticity in Tenebrio molitor (Coleoptera: Tenebrionidae): Analysis of Instar Variation in Number and Development Time under Different Diets. J. Entomol. Sci. 2010, 45, 75-90. [CrossRef]

10. Yang, S.S.; Wu, W.M.; Brandon, A.M.; Fan, H.Q.; Receveur, J.P.; Li, Y.; Wang, Z.Y.; Fan, R.; McClellan, R.; Gao, S.H. Ubiquity of polystyrene consumption and degradation by mealworms (the larvae of Tenebrio molitor) from different geographic sources. Chemosphere 2018, 212, 262-271. [CrossRef]

11. van Broekhoven, S.; Oonicx, D.G.; van Huis, A.; van Loon, J.J. Growth performance and feed conversion efficiency of three edible mealworm species (Coleoptera: Tenebrionidae) on diets composed of organic by-products. J. Insect Physiol. 2015, 73, 1-10. [CrossRef]

12. Oonincx, D.G.A.B.; van der Poel, A.F.B. Effects of diet on the chemical composition of migratory locusts (Locusta migratoria). Zoo Biol. 2011, 30, 9-16. [CrossRef]

13. Oonincx, D.G.A.B.; van Broekhoven, S.; van Huis, A.; van Loon, J.J.A. Feed conversion, survival and development, and composition of four insect species on diets composed of food by-products. PLoS ONE 2015, 10, e0144601. [CrossRef]

14. Dreassi, E.; Cito, A.; Zanfini, A.; Materozzi, L.; Botta, M.; Francardi, V. Dietary fatty acids influence the growth and fatty acid composition of the yellow mealworm Tenebrio molitor (Coleoptera: Tenebrionidae). Lipids 2017, 52, 285-294. [CrossRef] 
15. Hůrka, K. Brouci České a Slovenské Republiky, (in Czech, Beetles of the Czech and Slovak Republics); Kabourek: Zlín, Czech Republic, 2005; p. 390. ISBN 978-80-86447-17-9.

16. Yang, W.; Kenny, J.M.; Pulgia, D. Structure and properties of biodegradable wheat gluten bionanocomposites containing lignin nanoparticles. Ind. Crops Prod. 2015, 74, 348-356. [CrossRef]

17. Zielińska, E.; Zieliński, D.; Jakubczyk, A.; Karaś, M.; Pankiewiczt, U.; Flasz, B.; Dziewicka, M.; Lewicki, S. The impact of polystyrene consumption by edible insects Tenebrio molitor and Zophobas morio on their nutritional value, cytotoxicity, and oxidative stress parameters. Food Chem. 2021, 345, 128846. [CrossRef] [PubMed]

18. Yang, Y.; Yang, J.; Wu, W.M.; Zhao, J.; Song, Y.; Gao, L.; Yang, R.; Jiang, L. Biodegradation and mineralization of polystyrene by plastic-eating mealworms: Part 2. Role of gut microorganisms. Environ. Sci. Technol. 2015, 49, 12087-12093. [CrossRef]

19. Hagenmeyer, M. Food Information Regulation: Commentary on Regulation (EU) No. 1169/2011 on the Provision of Food Information to Consumers; Lexxion Verlagsgesellschaft: Berlin, Germany, 2012.

20. Janssen, R.H.; Vincken, J.P.; van den Broek, L.; Fogliano, V.; Lakemond, C. Nitrogen-to-protein conversion factors for three edible insects: Tenebrio molitor, Alphitobius diaperinus, and Hermetia illucens. J. Agric. Food Chem. 2017, 65, 2275-2278. [CrossRef]

21. Finke, M.D.; DeFoliart, G.R.; Benevenga, N.J. Use of a four-parameter logistic model to evaluate the quality of the protein from three insect species when fed to rats. J. Nutr. 1989, 119, 864-871. [CrossRef] [PubMed]

22. Ghosh, S.; Lee, S.-M.; Jung, C.; Meyer-Rochow, V.B. Nutritional composition of five commercial edible insects in South Korea. J. Asia Pac. Entomol. 2017, 20, 686-694. [CrossRef]

23. Zielińska, E.; Baraniak, B.; Karaś, M.; Rybczyńska, K.; Jakubczyk, A. Selected species of edible insects as a source of nutrient composition. Food Res. Int. 2015, 77, 460-466. [CrossRef]

24. Adámková, A.; Kouřimská, L.; Borkovcová, M.; Kulma, M.; Mlček, J. Nutritional valuse of edible coleoptera (Tenebrio molitor, Zophobas morio and Alphitobius diaperinus) reared in the Czech Republic. Potravinárstvo 2016, 10, 663-671. [CrossRef]

25. Jonas-Levi, A.; Martinez, J.J.I. The high level of protein content reported in insects for food and feed is overestimated. J. Food Compos. Anal. 2017, 62, 184-188. [CrossRef]

26. Bußler, S.; Rumpold, B.A.; Jander, E.; Rawel, H.M.; Schlüter, O.K. Recovery and techno-functionality of flours and proteins from two edible insect species: Meal worm (Tenebrio molitor) and black soldier fly (Hermetia illucens) larvae. Heliyon 2016, 2, e00218. [CrossRef] [PubMed]

27. Soxhlet, F. Die gewichtsanalytische Bestimmung des Milchfettes. Dinglers Polytech. J. 1879, 232, 461-465.

28. Vávra Ambrožová, J. Biologicky Aktivní Látky Mořských a Sladkovodních Řad (In Czech, Bioactive Compounds of Marine and Freshwater Algae). Ph.D. Thesis, Tomas Bata University, Zlín, Czech Republic, 2016.

29. Yi, L.; Lakemond, C.M.; Sagis, L.M.; Eisner-Schadler, V.; van Huis, A.; van Boekel, M.A. Extraction and characterisation of protein fractions from five insect species. Food Chem. 2013, 141, 3341-3348. [CrossRef]

30. Yang, S.S.; Brandon, A.M.; Flanagan, J.C.A.; Yang, J.; Ning, D.; Cai, S.-Y.; Fan, H.-Q.; Wang, Z.-Y.; Ren, J.; Benbow, E.; et al. Biodegradation of polystyrene wastes in yellow mealworms (larvae of Tenebrio molitor Linnaeus): Factors affecting biodegradation rates and the ability of polystyrene-fed larvae to complete their life cycle. Chemosphere 2018, 191, 979-989. [CrossRef] [PubMed]

31. Yang, Y.; Wang, J.; Xia, M. Biodegradation and mineralization of polystyrene by plastic-eating superworms Zophobas atratus. Sci. Total Environ. 2020, 708, 135233. [CrossRef] [PubMed]

32. Peng, B.-Y.; Su, Y.; Chen, Z.; Chen, J.; Zhou, X.; Benbow, M.E.; Criddle, C.S.; Wu, W.M.; Zhang, Y. Biodegradation of polystyrene by dark (Tenebrio obscurus) and yellow (Tenebrio molitor) mealworms (Coleoptera: Tenebrionidae). Environ. Sci. Technol. 2019, 53, 5256-5265. [CrossRef] [PubMed]

33. Bombelli, P.; Howe, C.J.; Bertocchini, F. Polyethylene bio-degradation by caterpillars of the wax moth Galleria mellonella. Curr. Biol. 2017, 27, 292-293. [CrossRef] [PubMed]

34. Kundungal, H.; Gangarapu, M.; Sarangapani, S.; Patchaiyappan, A.; Devipriya, S.P. Efficient biodegradation of polyethylene (HDPE) waste by the plastic-eating lesser waxworm (Achroia grisella). Environ. Sci. Pollut. Res. 2019, 26, 18509-18519. [CrossRef]

35. Božek, M.; Hanus-Lorenz, B.; Rybak, J. The studies on waste biodegradation by Tenebrio molitor. E3S Web Conf. EDP Sci. 2017, 17, 00011. [CrossRef]

36. Nukmal, N.; Rosa, E.; Kanedi, M. Insecticidal Effects of the Flavonoid-rich Fraction of Leaves Extract of Gamal (Gliricidia sepium) on the Coffee Mealybugs (Planococcus citri Risso). Annu. Res. Rev. Biol. 2017, 16, 1-9. [CrossRef]

37. Ravzanaadii, N.; Kim, S.-H.; Choi, W.-H.; Hong, S.-J.; Kim, N.-J. Nutritional value of mealworm, Tenebrio molitor as food source. Int. J. Ind. Entomol. 2012, 25, 93-98. [CrossRef]

38. Raheem, D.; Raposo, A.; Oluwole, O.B.; Nieuwland, M.; Saraiva, A.; Carrascosa, C. Entomophagy: Nutritional, ecological, safety and legislation aspects. Food Res. Int. 2019, 126, 108672. [CrossRef] [PubMed]

39. Bednářová, M.; Borkovcová, M.; Mlček, J.; Rop, O.; Zeman, L. Edible insects-species suitable for entomophagy under condition of Czech Republic. Acta Univ. Agric. Silvic. Mendel. Brun. 2013, 61, 587-593. [CrossRef]

40. Finke, M.D. Nutrient content of insects. In Encyclopedia of Entomology; Springer: New York, NY, USA, 2004; pp. $1563-1575$.

41. Ghaly, A.E.; Alkoaik, F.N. The yellow mealworm as a novel source of protein. Am. J. Agric. Biol. Sci. 2009, 4, 319-331. [CrossRef]

42. Rumpold, B.A.; Schlüter, O.K. Nutritional composition and safety aspects of edible insects. Mol. Nutr. Food Res. 2013, 57, 802-823. [CrossRef]

43. Li, L.; Zhao, Z.; Liu, H. Feasibility of feeding yellow mealworm (Tenebrio molitor L.) in bioregenerative life support systems as a source of animal protein for humans. Acta Astronaut. 2013, 92, 103-109. [CrossRef] 
44. Nowak, V.; Persijn, D.; Rittenschober, D.; Charrondiere, U.R. Review of food composition data for edible insects. Food Chem. 2016, 193, 39-46. [CrossRef]

45. Finke, M.D. Complete nutrient composition of commercially raised invertebrates used as food for insectivores. Zoo Biol. 2002, 21, 269-285. [CrossRef]

46. FAO. Fats and fatty acids in human nutrition. Report of an expert consultation. In FAO Food and Nutrition Paper; FAO: Rome, Italy, 2010; Volume 91, pp. 1-166. 